\title{
The First Identified Citrus tristeza virus Isolate of Turkey Contains a Mixture of Mild and Severe Strains
}

\author{
Bayram Çevik $^{1 *}$, Nejla Yardimci ${ }^{1}$ and Savaş Korkmaz ${ }^{2}$ \\ ${ }^{\prime}$ Department of Plant Protection, Faculty of Agriculture, Suleyman Demirel University, 32260 Isparta, Turkey \\ ${ }^{2}$ Department of Plant Protection, Faculty of Agriculture, Çanakkale Onsekizmart University, 17020 Çanakkale, Turkey \\ (Received on September 18, 2012; Revised on December 21, 2012; Accepted on January 18, 2013)
}

The presence of Citrus tristeza virus (CTV) has previously been reported in citrus growing regions of Turkey. All serologically and biologically characterized isolates including Iğdır, which was the first identified CTV isolates from Turkey, were considered mild isolates. In this study, molecular characteristics of the Iğdır isolate were determined by different methods. Analysis of the Iğdır isolate by western blot and BD-RT-PCR assays showed the presence of MCA13 epitope, predominantly found in severe isolates, in the Iğdır isolate revealing that it contains a severe component. For further characterization, the coat protein (CP) and the RNA-dependent RNA polymerase ( $R d R p)$ genes representing the 3 ' and 5 ' half of CTV genome, respectively, were amplified from dsRNA by RT-PCR. Both genes were cloned separately and two clones for each gene were sequenced. Comparisons of nucleotide and deduced amino acid sequences showed that while two $\mathrm{CP}$ gene sequences were identical, two RdRp clones showed only $90 \%$ and $\mathbf{9 1 \%}$ sequence identity in their nucleotide and amino acid sequences, respectively, suggesting a mixed infection with different strains. Phylogenetic analyses of the $C P$ and RdRp genes of Iğdır isolate with previously characterized CTV isolates from different citrus growing regions showed that the CP gene was clustered with NZRBTH30, a resistance breaking isolate from New Zealand, clearly showing the presence of severe component. Furthermore, two different clones of the RdRp gene were clustered separately with different CTV isolates with a diverse biological activity. While the RdRp-1 was clustered with T30 and T385, two well-characterized mild isolates from Florida and Spain, respectively, the RdRp-2 was most closely related to NZRB-G90 and NZRB-TH30, two well-characterized resistance breaking and stem pitting (SP) isolates from New Zealand confirming the mixed infection. These results clearly demonstrated that the Iğdır isolate, which was previously described as biologically a mild isolate, actually contains a mixture of mild and severe strains.

\footnotetext{
*Corresponding author.

Phone) +(246) 211-4737, FAX) +(246) 237-1693

E-mail)bayramcevik@sdu.edu.tr
}

Keywords : Citrus tristeza virus, Coat protein, Phylogenetic analysis, RNA-dependent RNA polymerase, Strain identification

Tristeza disease caused by Citrus tristeza virus (CTV), is one of the most destructive and economically important viral diseases limiting commercial citrus production worldwide (Bar-Joseph et al., 1989; Rocha-Pena et al., 1995). The disease is now distributed in almost all citrus growing regions of the world including Turkey (Moreno et al., 2008; Rocha-Pena et al., 1995). CTV is able to infect most species, varieties and hybrids of Citrus as well as some close relatives of Citrus (Muller and Garnsey, 1984). While most commercial Citrus varieties are sensitive to CTV, a citrus relative, Poncirus trifoliata, and some of its hybrids are resistant to this virus. Therefore, they were used as rootstock in some Citrus-growing regions including the Aegean and the Black Sea regions of Turkey. However, some isolates of CTV breaking the resistance in $P$. trifoliata were recently identified in New Zealand (Harper et al. 2009; Harper et al., 2010).

CTV is transmitted readily by grafting and several aphid species including Toxoptera citricida, Aphis gossypii and Aphis spiraecola are able to transmit the virus in a semipersistent manner in nature (Roistacher and Bar-Joseph, 1987). While T. citricida is the most efficient vector of CTV (Yokomi et al., 1994) and widely distributed in many Citrus-growing regions, $A$. gossypii, acts as a major vector, in some regions including Turkey where T. citricida is still absent. The recent detection and spread of T. citricida in Portugal and Spain (Ilharco et al., 2005) has become a significant concern for many Mediterranean countries such as Turkey where the majority of citrus are grown on CTVsensitive sour orange rootstocks.

CTV is a complex virus consisting of various strains causing a variety of symptoms in different Citrus hosts. Based on the symptoms inflicted on Citrus scions and rootstocks, CTV strains are divided into five major groups including mild (M), vein clearing in Mexican lime, seedling 
yellows (SY) in sour orange, lemon or grapefruit, quick decline (QD) in all Citrus species grafted on sour orange rootstock, and stem pitting on grapefruit (SP-G) and on sweet orange (SP-O) regardless of the rootstock. Symptoms of CTV isolates are determined experimentally using a previously established standardized set of Citrus indicator plants (Garnsey et al., 1987).

CTV is a single-stranded positive-sense RNA virus belonging to the genus Closterovirus in the Closteroviridae family. The long thread-like, flexuous, filamentous particles of CTV are about $2000 \mathrm{~nm}$ by $11 \mathrm{~nm}$ (Bar-Joseph et al., 1979; Bar-Joseph and Lee, 1990) and consist of one singlestranded positive-sense RNA molecule encapsidated with the major capsid protein $(\mathrm{CP})$ and minor CP (Febres et al., 1996). Sequencing of the complete genome of CTV isolates from different geographical origins and with various biological properties confirmed that CTV has one of the largest plant virus genomes ranging from 19226 to $19306 \mathrm{nt}$. The genome of CTV was organized into 12 open reading frames (ORF) potentially encoding 17 protein products, plus the $3^{\prime}$ and $5^{\prime}$ untranslated regions (UTRs) (Albiach-Marti et al., 2000; Harper et al., 2009; Harper et al., 2010; Karasev et al., 1995; Mawassi et al., 1996; Pappu et al., 1994; Suastika et al., 2001; Vives et al., 1999; Yang et al., 1999). The 25 $\mathrm{kDa}$ protein is the major capsid protein (Sekiya et al., 1991) encapsidating about $95 \%$ of the CTV genome. Therefore, the $\mathrm{CP}$ gene has been used as target for various methods developed for detection of CTV and strain identification including ELISA, western blot, peptide mapping, RT-PCR, hybridization and real-time RT-PCR. In addition the CP genes of a large number of CTV isolates from different geographical regions and biological properties have been cloned and sequenced (Mawassi et al 1993; Pappu, et al., 1993; Roy et al., 2003). Since a correlation between geographical origin and the biological characteristics of CTV isolates and their $\mathrm{CP}$ gene sequences was observed (Herrera-Isidrón et al., 2009), sequencing and the phylogenetic analysis of the $\mathrm{CP}$ gene was generally used for identification of newly identified and biologically uncharacterized CTV isolates (Niblett et al., 2000; Nolasco et al., 2009).

In Turkey, CTV was first detected symptomatically around Adana by Norman in 1963 and in Aegean Region by Özalp and Azari in 1967 (Baloglu and Birisik, 2009; Y1lmaz, 1999). The presence of CTV was demonstrated experimentally by serological and biological assays (Baloglu, 1988) and the first Turkish CTV isolate, Iğdır, was identified (Baloglu, 1988). Since then Iğdır and a limited number of other CTV isolates from Eastern Mediterranean region were characterized by serological and biological assays and these studies indicated that only mild isolates were present in Turkey (Baloğlu 1988; Korkmaz, 2002; Y1lmaz and Baloglu, 1998). After the detection of CTV in the Eastern Black Sea region by ELISA and RT-PCR (Korkmaz et al., 2006), the presence of CTV in all citrus growing regions of Turkey was confirmed. Therefore, the presence and distribution of CTV isolates in different citrus growing regions of Turkey is largely known and their serological and biological properties are determined to some extent. However, there is no sequence information available for Turkish CTV isolates and their molecular characteristics are completely unknown. In this study, molecular characteristics of the first identified CTV isolate, Iğdır, was determined by molecular tests used for strain identification and sequencing and phylogenetic analysis of the $\mathrm{CP}$ and the RdRp genes.

\section{Materials and Methods}

Virus isolate. The Iğdır isolate of CTV originally obtained from a sweet orange tree grafted on sour orange rootstock in a commercial orchard in Iğdır village of Mersin, Province located in the Eastern Mediterranean region of Turkey was used in this study. The isolate was originally found in the 1980s, identified by ELISA (Baloğlu 1988). It was later grafted and maintained on Mexican lime to date. Tissue samples of Mexican lime grafted with CTV Iğdır isolate were obtained from the Western Mediterranean Agricultural Research Institute (BATEM) in Antalya, Turkey where it is currently maintained as a reference isolate in a greenhouse. The samples of T30 and T36 used as mild and severe strains, respectively, were kindly provided by Richard F. Lee of USDA-ARS National Clonal Germplasm Repository for Citrus and Dates.

Oligonucleotide primers. The primers specific to the $\mathrm{CP}$ gene were designed based on the conserved sequences at the $5^{\prime}$ end (BC24 5'-ATGGACGACGAAACAAAGAA-3') and 3' end (BC25 5'-TCAACGTGTG TTGAATTTCC-3') of the CTV CP gene. Since the $5^{\prime}$ and $3^{\prime}$ ends of the RdRp gene were not conserved the primers specific to RdRp gene were designed based on conserved regions of located upstream (BC42 5'-CCTACTGAATATAAGGGTAG-3') and down-stream (BC43 5'-CTCGCGAAGGCAAACAT-3') of the RdRp gene. The primers for the bidirectional PCR were previously reported (Çevik et al., 1996).

Amplification of the CP and RdRp genes by RT-PCR. dsRNA was isolated using a previously reported dsRNA isolation method (Morris and Dodds, 1979) with minor modification. The $\mathrm{CP}$ and RdRp genes of the Iğdır isolate were amplified from dsRNA by a two-step reverse transcription-polymerase chain reaction (RT-PCR) assay using AMV reverse transcriptase and $P f u$ DNA polymerase (Promega, USA). First, $5 \mathrm{ml}$ of dsRNA was denatured at $95^{\circ} \mathrm{C}$ for 5 min and quickly chilled on ice. cDNA was synthesized 
from denatured dsRNA in $20 \mu \mathrm{l}$ mixture containing $1 \mathrm{X}$ AMV first strand buffer (50 mM Tris $\mathrm{HCl}$ pH 8.3, $75 \mathrm{mM}$ $\mathrm{KCl}, 3 \mathrm{mM} \mathrm{MgCl}$ ), 20 units RNAsin (Promega, USA), 0.5 $\mathrm{mM}$ dNTPs, 20 units AMV reverse transcriptase (Promega, USA) and 20 pmol random hexamers using the MJ Mini thermal cycler PTC1148 (Bio-Rad, USA) programmed at $30^{\circ} \mathrm{C}$ for $10 \mathrm{~min}$. followed by $42^{\circ} \mathrm{C}$ for $60 \mathrm{~min}$ and $75^{\circ} \mathrm{C}$ for $15 \mathrm{~min}$

PCR was conducted in $50 \mu 1$ reaction mixture containing 1X Pfu reaction buffer $\left[20 \mathrm{mM}\right.$ Tris- $\mathrm{HCl}\left(\mathrm{pH} 8.8\right.$ at $\left.25^{\circ} \mathrm{C}\right)$, $10 \mathrm{mM}\left(\mathrm{NH}_{4}\right)_{2} \mathrm{SO}_{4}, 100 \mathrm{mM} \mathrm{KCl}, 1 \%$ (v/v) Triton X-100, 1 $\mathrm{mg} / \mathrm{ml} \mathrm{BSA}$ and $20 \mathrm{mM} \mathrm{MgSO}_{4}$ ], $0.2 \mathrm{mM}$ dNTPs, 2.5 unit Pfu DNA polymerase (Promega, USA) $5 \mu \mathrm{l}$ of cDNA and 20 pmol of primer specific to CP (BC24 and 25) and RdRp (BC42 and BC43) genes. PCR was performed in the MJ Mini thermal cycler PTC1148 (Bio-Rad, USA) programmed for initial denaturation at $94^{\circ} \mathrm{C}$ for $3 \mathrm{~min}$ and then, 40 cycles of denaturation at $94^{\circ} \mathrm{C}$ for $30 \mathrm{~s}$, primer annealing at $55^{\circ} \mathrm{C}$ for $30 \mathrm{~s}$, and primer extension at $72^{\circ} \mathrm{C}$ for $1 \mathrm{~min}$ for the $\mathrm{CP}$ gene and $2 \mathrm{~min}$ for the $\mathrm{RdRp}$ gene followed by final extension at $72^{\circ} \mathrm{C}$ for $5 \mathrm{~min}$. PCR products were separated in $1 \%$ agarose gel with 100 bp DNA size marker, stained with ethidium bromide and visualized and analyzed by Doc-It system (UVP, England).

Bidirectional RT-PCR (BD-RT-PCR) assay. BidirectionalRT-PCR (BD-RT-PCR) method was develop to differentially amplify $300 \mathrm{bp}$ or $400 \mathrm{bp}$ fragment along with full-length $\mathrm{CP}$ gene of isolates with or without the MCA13 epitope, respectively, for strain identification (Çevik et al., 1996). BD-RT-PCR was performed as previously described to determine if the CP gene Iğdır isolate contains MCA13 epitope predominantly associated with isolates considered as severe. PCR products were separated in 1.5\% agarose gel and analyzed as described in the previous section.

Western blot analysis. Bark tissue from Mexican limes seedlings infected with the Iğdır isolate was ground to powder in liquid nitrogen using a mortar and passel. About $200 \mathrm{mg}$ ground tissue was homogenized in $0.5 \mathrm{ml} 2 \mathrm{X}$ extraction buffer containing $0.125 \mathrm{M}$ Tris- $\mathrm{HCl}$ at $\mathrm{pH} 6.8$, $4 \%$ SDS, $20 \%$ glycerol, and 10\% 2-mercaptoethanol. The homogenate was incubated at $95^{\circ} \mathrm{C}$ for $5 \mathrm{~min}$, cooled down to room temperature and briefly centrifuged to separate cellular debris. Supernatant was loaded onto a 12\% SDS polyacrylamide gel and total protein was separated by electrophoresis, and transferred to a nitrocellulose membrane (Stratagene, USA) using a Mini Transblot (Bio-Rad, USA). The membrane was probed with the MCA13 monoclonal antibody (Permar et al., 1990) (kindly provided by Richard F. Lee), followed by rabbit anti-mouse IgG conjugated with alkaline phosphatase (Promega, USA). The presence of the
$25 \mathrm{kDa}$ major $\mathrm{CP}$ was detected colorimetrically with a $\mathrm{p}$ nitrophenol phosphate substrate (Sigma, USA).

Cloning of the CP and RdRp genes. The CP and RdRp genes amplified by RT-PCR from Iğdır isolate were separated in $1 \%$ agarose gel, appropriate bands were excised from the gel and purified using the Qiaquick gel purification kit (Qigene, Germany) according to the manufacturer's instructions. For making compatible ends for T-A cloning an adenine (A) overhang was added to the 3 ' ends of the purified DNA by Taq DNA polymerase by A-tailing method. A-tailed PCR products $(5 \mu \mathrm{l})$ were ligated into the pGEMTeasy plasmid vector (Promega, USA) at $4^{\circ} \mathrm{C}$ for $16 \mathrm{hr}$ using T4 DNA ligase and $1 \mathrm{X}$ ligation buffer $(0.05 \mathrm{M}$ Tris$\mathrm{HCl} \mathrm{pH}$ 8.0, $0.01 \mathrm{M} \mathrm{MgCl}_{2} 1 \mathrm{mM}$ ATP and $50 \mu \mathrm{g} / \mathrm{ml}$ bovine serum albumin). Competent cells of Escherichia coli strain JM109 were transformed with ligation mixture by heat shock at $42^{\circ} \mathrm{C}$ for $1 \mathrm{~min}$. Transformed cells were plated and grown in LB medium (1\% bacto-tryptone, $0.5 \%$ bacto-yeast extract, $0.5 \% \mathrm{NaCl}$ ) containing $100 \mu \mathrm{g} / \mu \mathrm{l}$ ampicillin, $25 \mu \mathrm{g} / \mathrm{ml}$ 5-bromo-4-chloro-Indoly- $\beta$-D-galactoside (X-Gal) and $0.1 \mathrm{M}$ isopropyl-beta-thio galactopyranoside (IPTG) at $37^{\circ} \mathrm{C} 16 \mathrm{hr}$. Recombinant colonies carrying pGEM-Teasy plasmid vector with the CP or RdRp genes were selected by blue/white screening on LB medium according to the manufacturer's instructions. For each sample, at least five white colonies were screened by colony PCR and at least two colonies carrying the pGEM-T Easy plasmid with the $\mathrm{CP}$ and RdRp genes were identified. Plasmids were isolated from these colonies and the presence of the CP and RdRp genes in the plasmids were confirmed by EcoRI digestion.

Sequencing and sequence analysis of the CP and RdRp genes. The cloned $\mathrm{CP}$ and $\mathrm{RdRp}$ genes were sequenced in both directions by automated cycle sequencing using M13 forward and reverse primers. The sequences of the $\mathrm{CP}$ and RdRp genes were assembled and analyzed using Vector NTI Suite program (Invitrogen, USA). The sequences were compared with each other and other $\mathrm{CP}$ and $\mathrm{RdRp}$ gene sequences in the GenBank. Multiple sequence alignments of the full-length amino acid sequences of the $\mathrm{CP}$ and the RdRp genes were conducted by the AlignX Module of Vector NTI Suite. The phylogenetic analysis was performed by Clustal X2 program using neighbor joining algorithm and tested by a bootstrap analysis with 1000 replications. Constructed phylogenetic trees were visualized by TreeView program.

\section{Results}

Characterization of the Iğdır isolate. Previously identi- 


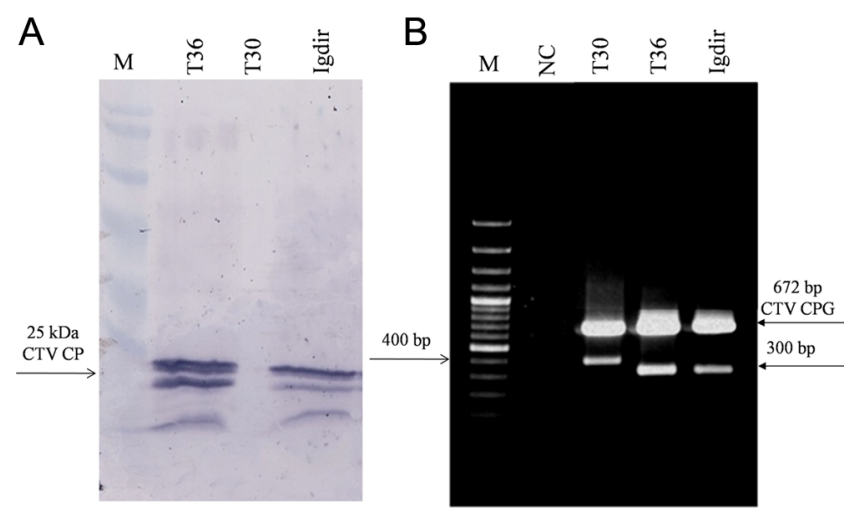

Fig. 1. Detection of MCA13 epitope, which is predominantly found in severe strains, in Iğdır isolates of CTV using Western blot (A) and BD-RT-PCR (B) assays. M: DNA or protein size marker; T30: a mild isolate from Florida do not contain the MCA13 epitope; T36: a decline-inducing severe isolate from Florida containing the MCA13 epitope.

fied Iğdır isolate maintained in Mexican lime as reference mild isolate of CTV was tested by Western blot with MCA13 antibody and the BD-RT-PCR developed based on the MCA13 epitope in CP. Therefore, Western blot was used to determine if the Iğdır isolate react with MCA13 antibody, which is predominantly used for identification of severe, especially QD, strain of CTV. Western blot analysis of the Iğdır isolate was conducted along with T30 and T36, reference for mild and severe strains, respectively. Western blot analysis with MCA13 antibody showed that while T30 did not react with MCA13, T36 and the Iğdır isolate both reacted with MCA13 and a $25 \mathrm{kDa}$ protein corresponding to the $\mathrm{CP}$ was detected in both samples. The result showed that the Iğdır isolate previously characterized as mild contains the MCA13 epitope associated with severe isolates (Fig. 1A).

The BD-RT-PCR method previously developed for strain identification based on a single nucleotide change in the MCA13 epitope of the CP gene was used to confirm the Western blot results, suggesting that the Iğdır isolate may contain a severe component. The BD-RT-PCR assay was conducted for the Iğdır isolate along with T30 and T36, reference isolates for mild and severe strains, respectively. Using the BD-RT-PCR method, a full-length CPG (700 bp) and a $400 \mathrm{bp}$ fragment specific to mild strains were produced from the mild strain T30 (Fig. 2B). On the other hand about $700 \mathrm{bp}$ fragment corresponding to the fulllength $\mathrm{CP}$ gene as well as a $300 \mathrm{bp}$ fragment specific to MCA13 positive severe strains were amplified from the severe QD strain T36 and the Iğdır isolate (Fig. 1B). No DNA fragment was amplified from the healthy Mexican lime samples used as negative control. The results demonstrated that the BD-RT-PCR method worked properly and clearly showed that the $\mathrm{CP}$ of the Iğdır isolate contains the

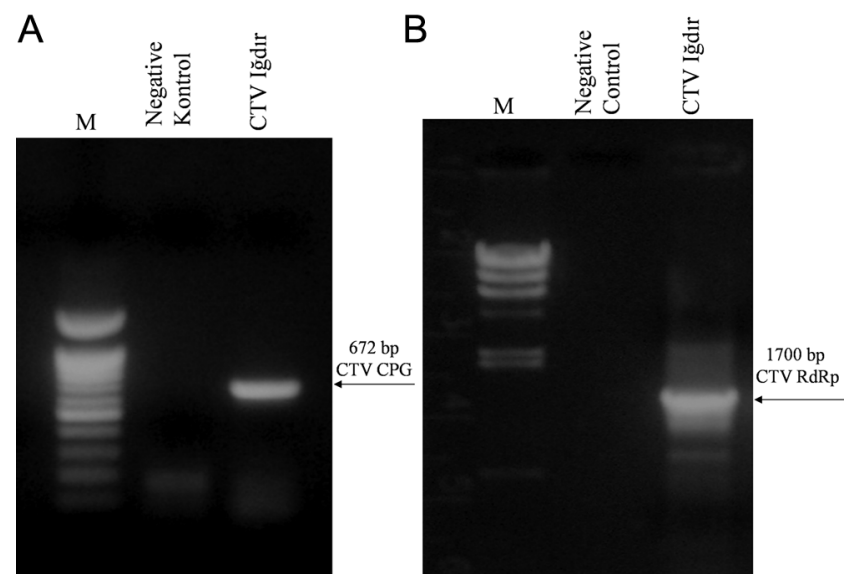

Fig. 2. Amplification of the $\mathrm{CP}(\mathrm{A})$ and the RdRp (B) genes of Iğdır isolate by RT-PCR. M: DNA size marker; Negative control: uninfected Mexican lime. The sizes of the amplified DNA fragment are indicated by arrows.

MCA13 epitope predominantly found in severe strains of CTV. These findings supported the Western blot data and confirmed that the Iğdır isolate contains the MCA13 epitope sequence associated with severe isolates.

Cloning the CP and RdRp genes. RT-PCR tests were conducted for amplification of the CP and RdRp genes of Iğdır isolate of CTV. While DNA fragments of about 700 bp and 1700 bp corresponding to the CP and the RdRp genes, respectively, was amplified by RT-PCR from cDNA synthesized from the dsRNA isolated from Mexican lime infected with the Iğdır isolate of CTV (Fig. 2), no DNA was amplified from the dsRNA isolated from uninoculated Mexican lime (Fig. 2). The results showed that Mexican lime used as maintenance host still contained the Iğdır isolate of CTV and primers designed based on the $\mathrm{CP}$ and RdRp sequences were suitable for amplification of both genes. Therefore, amplification of the $\mathrm{CP}$ and RdRp genes enable molecular characterization of the Iğdır isolate using two different genomic regions.

The CP and RdRp genes were cloned in to pGEM-Teasy plasmid vector using T-A cloning method. A number of recombinant colonies potentially carrying the $\mathrm{CP}$ and $\mathrm{RdRp}$ genes were obtained in initial blue-white screening. At least 10 colonies for each gene were selected and tested by a colony PCR and the presence of the CP and RdRp gene was confirmed in majority of these colonies. Two colonies carrying the pGEM-T easy plasmid with the CP and RdRp genes designated as pGEM-T Iğdır CP-1, pGEM-T Iğdır CP-2, pGEM-T Iğdır RdRp-1 and pGEM-T Iğdır RdRp-2 were selected and plasmid was purified and digested with EcoRI. Digestion of pGEM-Teasy plasmids carrying the $\mathrm{CP}$ gene revealed an about 750 bp band containing the $\mathrm{CP}$ gene and $3000 \mathrm{bp}$ band of pGEM-Teasy plasmid in both clones (Fig. 


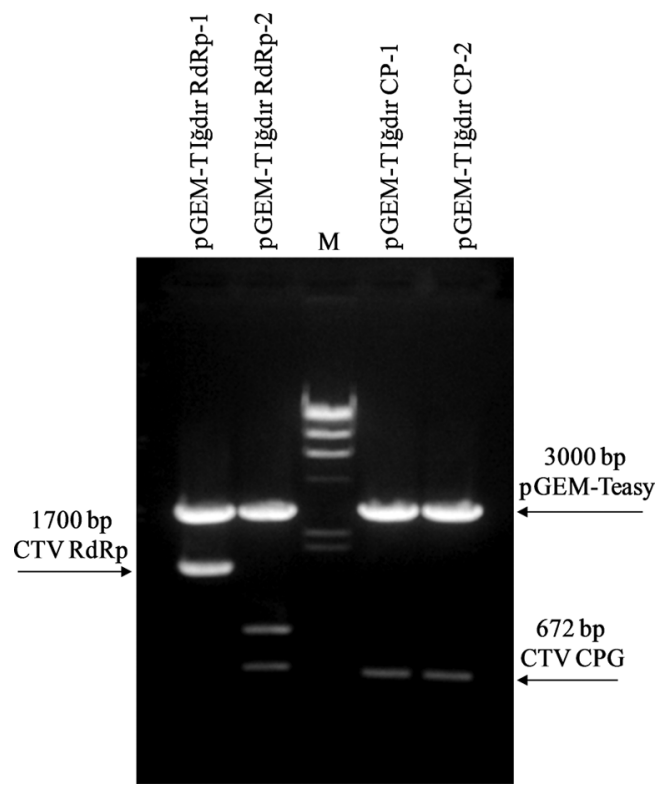

Fig. 3. Restriction digestion of the pGEM-Teasy plasmid vector with cloned $\mathrm{CP}$ and RdRp genes of Iğdır isolate with EcoRI. M: DNA size marker. The sizes of the cloned DNA fragment after EcoRI digestion are indicated by arrows.
3). On the other hand, the digestion of the pGEM-Teasy plasmids carrying the RdRp gene produced different pattern in two different clones. While digestion of pGEM-T Iğdır RdRp-1 clone produced two bands of about $1700 \mathrm{bp}$ and 3000 bp corresponding to RdRp gene and pGEM-Teasy respectively, the other clone produced three different bands. The 3000 bp corresponded pGEM-Teasy vector, the other two fragments (700 and $1000 \mathrm{bp}$ ) together corresponded to the RdRp gene suggesting that it has an internal EcoRI site (Fig. 3). The results demonstrated that the CP and RdRp genes were successfully cloned and two different clones for each gene were obtained. Different restriction patterns produced by EcoRI digest of the RdRp clones suggested that these clones contained some sequence variation and the Iğdır isolate may contain a mixture of different CTV strains.

Sequence analysis of the $C P$ and $R d R p$ genes. The nucleotide sequence of two different clones of the CP (Iğdır CP-1 and CP-2) and the RdRp (Iğdır RdRp-1 and RdRp-2) genes were determined and submitted to the GenBank database under the accession KC349866, KC349867, KC349868

A

1 (1) 75

TGDIR-CP-2 (1) MDDETKKLKNKTKETKEGDDVVAAESSFGS INLHIDPTLIAMNDVRQLGTQQNAALNRDLFLTLKGKHPNLPDKD

Consensus (1) MDDETKKLKNKTKETKEGDDVVAAESSFGSINLHIDPTLIAMNDVRQLGTQQNAALNRDLFLTLKGKHPNLPDKD 76

150

IGDIR-CP-1 (76) KDFHIAMMLYRLAVKSSSLQSDDDTTGITYTREGVEVDLPDKLWTDVVFNSKGIGNRANALRVWGRTNDALYLAF

IGDIR-CP-2 (76) KDFHIAMMLYRLAVKSSSLQSDDDTTGITYTREGVEVDLPDKLWTDVVENSKGIGNRANALRVWGRTNDALYLAF

Consensus (76) KDFHIAMMLYRLAVKSSSLQSDDDTTGITYTREGVEVDLPDKLWTDVVFNSKGIGNRANALRVWGRTNDALYLAF $151 \quad 223$

$\begin{array}{lll}\text { IGDIR-CP-1 } & (151) & \text { CRQNRNLSYGGRPLDAGI PAGYHYLCADFLTGAGLTDLECAVYIQAKEQLIKKRGADEVVVTNVRQLGKFNTR } \\ \text { IGDIR-CP-2 } & \text { (151) } & \text { CRONRNLSYGGRPLDAGIPAGYHYLCADFLTGAGLTDLECAVYIOAKEOLIKKRGADEVVVTNVROLGKFNTR }\end{array}$

B

Consensus (151) CRONRNLSYGGRPLDAGI PAGYHYLCADFLTGAGLTDLECAVYIOAKEOL.LKKRGADEVVVTNVROLGKFNTR

Igdir RdRp 1 Igdir RdRp

(1) GTLLPRTLVIYTNRLVEGVVRSQAIPPRKASLQENLLSYESRNYNFIKTERFVGPEGFGRAMAAAVIERCFKMDE

(1) ETRPLPTPVTYTNRLVFGVVRSOA IPPRKASLOENLLSYESRNYNFIKTEREVGPSEFGRAMAAAVIETCEKMEE

(1) $\mathrm{T} T \mathrm{~T}$ YTNRLVFGVVRSOAIPPRKASLQENLLSYESRNYNFIKTERFVGP FGRAMAAAVIE CFKMDE

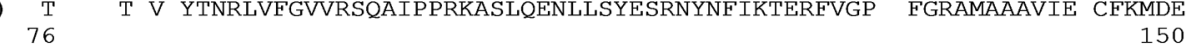

(76) VAKIRSDIIALTEANIKKWLDKRTPCQVKSVQAELKLPFTVEEQVTNYKLMVKRDAKVKLDDSSLSKHPAAQNIM

(76) MAKIRCDIISLTEANILKWLDKRTPCQIKAVQAELKLPESVEEQITNYRLMVKRDAKVKLDDSSLSKHPAAQNIM

Igdir RdRp

Igdir RdRp 2

Consensus

Igdir RdRp 1

Igdir RdRp 2

Consensus

Igdir RdRp 1

Igdir RdRp 2

Consensus

Igdir RdRp 1

Igdir RdRp 2

Consensus

Igdir RdRp 1

Igdir RdRp 2

Consensus

Igdir RdRp 1

Igdir RdRp 2

Consensus

(76) MAKIR DIIALTEANI KWLDKRTPCQIKAVQAELKLPFSVEEQITNYKLMVKRDAKVKLDDSSLSKHPAAQNIM 151

(151) FHKKFINAIYSPCFDEFKNRVLSSLNGNIVFFTEMTNAGLAEVVRRIIGDDDNLFAGEVDFSKFDAVSRFVHQES

(151) FHKKLINAIFSPCEDEFKNRVLSSLNDNIVFFTEMTNAGLAEVIRRIVGDDDNLFVGEVDFSKCDKVSGFVHKES

(151) FHKK INAIFSPCFDEFKNRVLSSLN NIVFFTEMTNAGLAEVIRRIIGDDDNLF GEVDFSK D VS FVH ES 226

(226) SVRCTLSSGSTTNFSTCGWKASTALGLPRLDGOLSFSVDGORRSGGSNTWIGNSLVTLGILSLYYDVSKFELLLV

(226) NVRYIPSSVSTTNF SLCGWKSSIALGRLRFDCQLSFSVDVQRRSGGSNTWI GNSLVTLGILSLYYDVSKFELLII

(226) VR I SS STTNFS CGWKAS ALG R D QLSFSVD QRRSGGSNTWIGNSLVTLGILSLYYDVSKFELLLI 301

(301) SGDDSLIYSKEKISNFSSEICLETGEETKFMS PSVPYCSKFMVOTGNKTCFVPDPYKLLVKLGAXOYKLTDDEI

(301) SGDDSLIYSSEKISNYSSEICLETGEETKEMSPSVPYFCSKFVVOTGNKTCEVPDPYKLLVKLGAPONKLTDDEI

(301) SGDDSLIYS EKISNFSSEICLETGFETKFMSPSVPYFCSKFMVQTGNKTCFVPDPYKLLVKLGA Q KLTDDEL 376

450

(376) FELFTSFEDITQDFGDQVVLGXLKLLVETKYSFTSGTTMPALCAIHCVRSNYLSFERLFPFIRGWYVVDALKLRQ

(376) FELFTSFKDITQDFGDQVVLEKLKLLVEAKYGFTSGTTMPALCAI HCVRSNYLSEERLFPFIRGWYVVDALKLRQ

(376) FELFTSF DITQDFGDQVVL LKLLVE KY FTSGTTMPALCAIHCVRSNYLSFERLFPFIRGWYVVDALKLRQ 451

494

(451) LRKFTNLICERVVYDNRVGYFSHEDSPEDKPDASDGOADDLVTG

(451) LRKFANLICERIVYDNRVGYFSYFDNPETKPDASDGQMDDLVTS

(451) LRKF NLICERIVYDNRVGYFSHFD PF KPDASDGQ DDLV'

Fig. 4. Amino acid sequence alignment of two different clones of the $\mathrm{CP}(\mathrm{A})$ and the $\mathrm{RdRp}(\mathrm{B})$ genes of Iğdır isolate. The positions of amino acids are indicated above the sequence. The identical and similar amino acids are highlighted in yellow and green, respectively. The GenBank accession numbers for the Iğdır CP-1, CP-2, RdRp-1 and RdRp-2 are KC349866, KC349867, KC349868 and KC349869, respectively. 
Table 1. Percent amino acid sequence identity of the RdRp gene of Iğdır isolates with other CTV isolates from different Citrus-growing regions of the world

\begin{tabular}{|c|c|c|c|c|c|c|c|c|c|c|c|c|c|c|}
\hline Isolates & $\begin{array}{l}\text { IGDIR- } \\
2 \text { RdRp }\end{array}$ & $\begin{array}{l}\text { Mexico } \\
\text { RdRp }\end{array}$ & $\begin{array}{l}\text { NUAG } \\
\text { A RdRp }\end{array}$ & $\begin{array}{l}\text { NZ } 18 \\
\text { RdRp }\end{array}$ & $\begin{array}{c}\text { NZ } \\
\text { M16 } \\
\text { RdRp }\end{array}$ & $\begin{array}{c}\text { NZRB } \\
\text { G90 } \\
\text { RdRp }\end{array}$ & $\begin{array}{l}\text { QAHA } \\
\text { RdRp }\end{array}$ & $\begin{array}{c}\text { T30 } \\
\text { RdRp }\end{array}$ & $\begin{array}{l}\text { T318A } \\
\text { RdRp }\end{array}$ & $\begin{array}{c}\text { T36 } \\
\text { RdRp }\end{array}$ & $\begin{array}{l}\text { T385 } \\
\text { RdRp }\end{array}$ & $\begin{array}{c}\text { VT } \\
\text { RdRp }\end{array}$ & $\begin{array}{l}\text { NZRB } \\
\text { TH30 } \\
\text { RdRp }\end{array}$ & $\begin{array}{l}\text { IGDIR- } \\
1 \text { RdRp }\end{array}$ \\
\hline B165 RdRp & 91 & 86 & 94 & 98 & 95 & 93 & 88 & 94 & 94 & 90 & 94 & 94 & 92 & 92 \\
\hline IGDIR-2 RdRp & & 89 & 91 & 88 & 90 & 97 & 91 & 91 & 91 & 93 & 91 & 91 & 96 & 90 \\
\hline MEXICO RdRp & & & 87 & 84 & 86 & 91 & 95 & 87 & 87 & 96 & 87 & 87 & 91 & 86 \\
\hline NUAGA RdRp & & & & 92 & 96 & 93 & 89 & 96 & 100 & 90 & 96 & 99 & 92 & 95 \\
\hline NZ B18 RdRp & & & & & 92 & 91 & 86 & 92 & 92 & 88 & 92 & 92 & 90 & 90 \\
\hline NZ M16 RdRp & & & & & & 92 & 88 & 96 & 96 & 90 & 96 & 97 & 93 & 94 \\
\hline NZRB G90 RdRp & & & & & & & 94 & 94 & 93 & 95 & 94 & 93 & 98 & 92 \\
\hline QAHA RdRp & & & & & & & & 89 & 89 & 98 & 89 & 89 & 94 & 88 \\
\hline T30 RdRp & & & & & & & & & 96 & 91 & 100 & 96 & 93 & 95 \\
\hline T318A RdRp & & & & & & & & & & 91 & 96 & 99 & 93 & 95 \\
\hline T36 RdRp & & & & & & & & & & & 91 & 91 & 95 & 90 \\
\hline T385 RdRp & & & & & & & & & & & & 96 & 93 & 95 \\
\hline VT RdRp & & & & & & & & & & & & & 92 & 95 \\
\hline NZRBTH30 RdRp & & & & & & & & & & & & & & 92 \\
\hline
\end{tabular}

and KC349869. The nucleotide and the deduced amino acid sequences of two different clones of the $\mathrm{CP}$ gene from the Iğdır isolate were $100 \%$ identical (Fig. 4A, Table 1). However, two different clones of the RdRp gene from the Iğdır isolate shared only $90 \%$ nucleotide sequence identity and only $91 \%$ amino acid sequence identity with each other (Fig. 4A, Table 2). The amino acid sequence comparisons of different clones of the RdRp and CP genes of the Iğdır isolates is shown in Fig. 4. These results showed that while two clones of the $\mathrm{CP}$ genes were identical, the RdRp clones were different indicating that two RdRp clones were derived from mixed infection of more than one isolate. To determine the phylogenetic relationships and possible biological activity of the potential isolates in the mixed infection, the deduced amino acid sequences of the $\mathrm{CP}$ and RdRp genes from the Iğdır isolate were compared with respective genes from well-characterized CTV isolates from other Citrus growing regions of the world available in the GenBank databases.

Multiple alignment and comparison of the $\mathrm{CP}$ genes revealed that the Iğdır isolate shared 95 to $98 \%$ amino acid sequence identity to other CTV isolates. With $98 \%$ sequence

Table 2. Percent sequence identity of the CP gene of Iğdır isolates with other CTV isolates from different Citrus-growing regions of the world

\begin{tabular}{|c|c|c|c|c|c|c|c|c|c|c|c|c|c|c|}
\hline Isolates & $\begin{array}{c}\text { IGDIR- } \\
1 \mathrm{CP}\end{array}$ & $\begin{array}{c}\text { IGDIR } \\
2 \mathrm{CP}\end{array}$ & $\begin{array}{l}\text { MEX- } \\
\text { ICO CP }\end{array}$ & $\begin{array}{l}\text { NUAC } \\
\text { A CP }\end{array}$ & $\begin{array}{l}\text { JZB18 } \\
\text { CP }\end{array}$ & $\begin{array}{c}\text { NZ M16 } \\
\text { CP }\end{array}$ & $\begin{array}{l}\text { NZ RB } \\
\text { G90 CP }\end{array}$ & $\begin{array}{l}\text { NZ RB } \\
\text { TH30 }\end{array}$ & $\begin{array}{c}\text { QAHA } \\
\text { CP }\end{array}$ & $\begin{array}{l}\text { T30 } \\
\text { CP }\end{array}$ & $\begin{array}{c}\text { T318A } \\
\text { CP }\end{array}$ & $\begin{array}{l}\text { T36 } \\
\text { CP }\end{array}$ & $\begin{array}{c}\text { T385 } \\
\text { CP }\end{array}$ & $\begin{array}{l}\text { VT } \\
\text { CP }\end{array}$ \\
\hline $\mathrm{B} 165 \mathrm{CP}$ & 97 & 97 & 96 & 100 & 100 & 98 & 98 & 97 & 96 & 96 & 99 & 96 & 96 & 97 \\
\hline IGDIR-1 CP & & 100 & 96 & 96 & 97 & 97 & 96 & 98 & 96 & 95 & 96 & 96 & 95 & 96 \\
\hline IGDIR-2 CP & & & 96 & 96 & 97 & 97 & 96 & 98 & 96 & 95 & 96 & 96 & 95 & 96 \\
\hline MEXICO CP & & & & 95 & 96 & 95 & 95 & 95 & 100 & 96 & 96 & 100 & 96 & 94 \\
\hline NUAGA CP & & & & & 100 & 97 & 97 & 97 & 95 & 96 & 99 & 95 & 96 & 97 \\
\hline NZ B18 CP & & & & & & 98 & 98 & 97 & 96 & 96 & 99 & 96 & 96 & 97 \\
\hline NZ M16 CP & & & & & & & 96 & 96 & 95 & 96 & 97 & 95 & 97 & 96 \\
\hline NZ RB G90 CP & & & & & & & & 96 & 95 & 96 & 97 & 95 & 96 & 96 \\
\hline NZ RB TH30 CP & & & & & & & & & 95 & 95 & 96 & 95 & 95 & 96 \\
\hline QAHA CP & & & & & & & & & & 96 & 96 & 100 & 96 & 94 \\
\hline T30 CP & & & & & & & & & & & 96 & 96 & 99 & 95 \\
\hline T318A CP & & & & & & & & & & & & 96 & 96 & 96 \\
\hline Т36 CP & & & & & & & & & & & & & 96 & 94 \\
\hline T385 CP & & & & & & & & & & & & & & 95 \\
\hline
\end{tabular}


identity the CP gene of the Iğdır isolate was most similar with the CP gene of NZRB-TH30 (Table 1), a resistance breaking amino acid isolate from New Zealand (Harper et al., 2009; Harper et al., 2010). This isolate is able to break the CTV resistance and replicate in P. trifoliata and also cause severe stem pitting on sweet orange. Interestingly, the $\mathrm{CP}$ gene of the Iğdır isolate was the least similar to that of two well- characterized mild isolates, T30 from Florida and T385 from Spain with 95\% sequence identity (Table 1). The results clearly demonstrated that the Iğdır isolates contains a severe component and both clones of the CP gene were derived from this severe component of the mixed infection.

On the other hand, multiple alignment and comparison of deduced amino acid sequences of two different clones of the RdRp from Iğdır shared different sequence identity with the RdRp of other CTV isolates. While the RdRp-1 showed 88 to $97 \%$ identity, the RdRp-2 shared 86 to $95 \%$ amino acid sequence identity with RdRps from other CTV isolates. The RdRp-1 was 95\% identical to five isolates with different biological characteristics, but it was most similar to T30 and T385, two well-characterized mild isolates from Florida and Spain, respectively (Table 2). With 86 and $88 \%$ identity it was the most different from a QD isolates from Mexico and QAHA from Egypt, respectively (Table 2). In contrast, with 96 and 97\% identity the RdRp-2 was most similar to

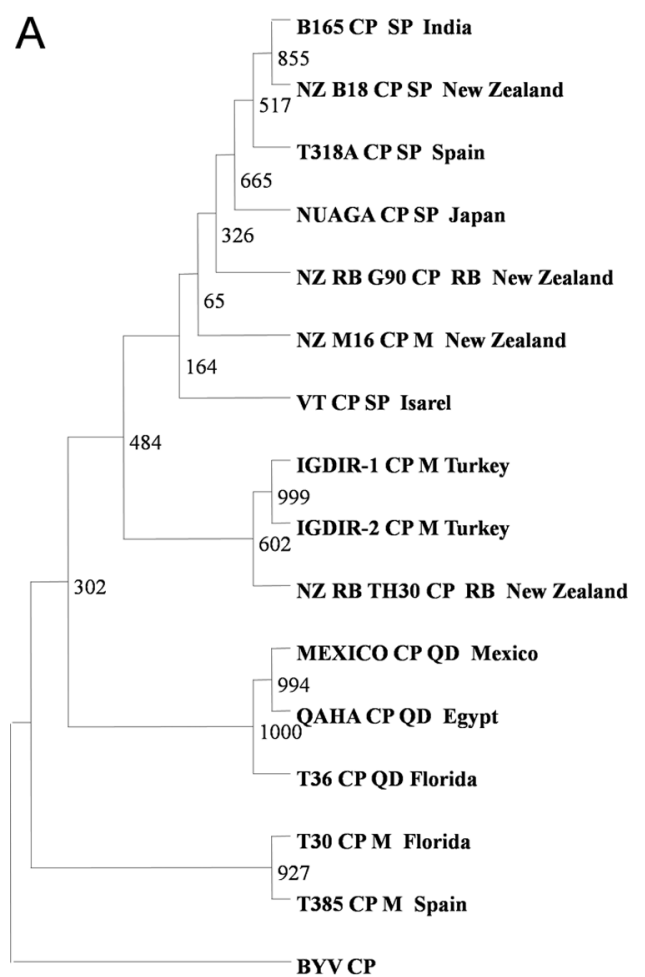

NZRB-G90 and NZRB-TH30 two characterized RB and SP causing isolates from New Zealand (Table 2). It was the least similar to an orange SP isolate NZ-B18 from New Zealand and a QD isolate from Mexico, with 88 and $89 \%$ sequence identity, respectively (Table 2). The result revealed that two different clones of RdRp from the Iğdır isolates show homology with the RdRp of CTV isolates with very different biological activity one being $M$ and the other being the most severe RB isolates of CTV from different citrus growing regions.

Phylogenetic relationships of the Iğdır isolate with previously characterized CTV isolates from different citrus growing regions was determined by comparing the amino acid sequences of the CP and RdRp genes. The phylogenetic analysis of the $\mathrm{CP}$ gene revealed four main isolates groups with different biological activity supported by high bootstrap values. The Iğdır isolate were clustered with NZRB-TH30, a RB isolate from New Zealand (Fig. 5). The results showed that two different clones of the CP gene with identical amino acid sequences were closely related with a severe stem pitting isolate enable to break CTV resistance in P. trifoliata confirming that the Iğdır isolate contains a severe component. On the other hand, although the a similar phylogenetic tree was constructed using the RdRp genes of different CTV isolates, two different clones of the RdRp

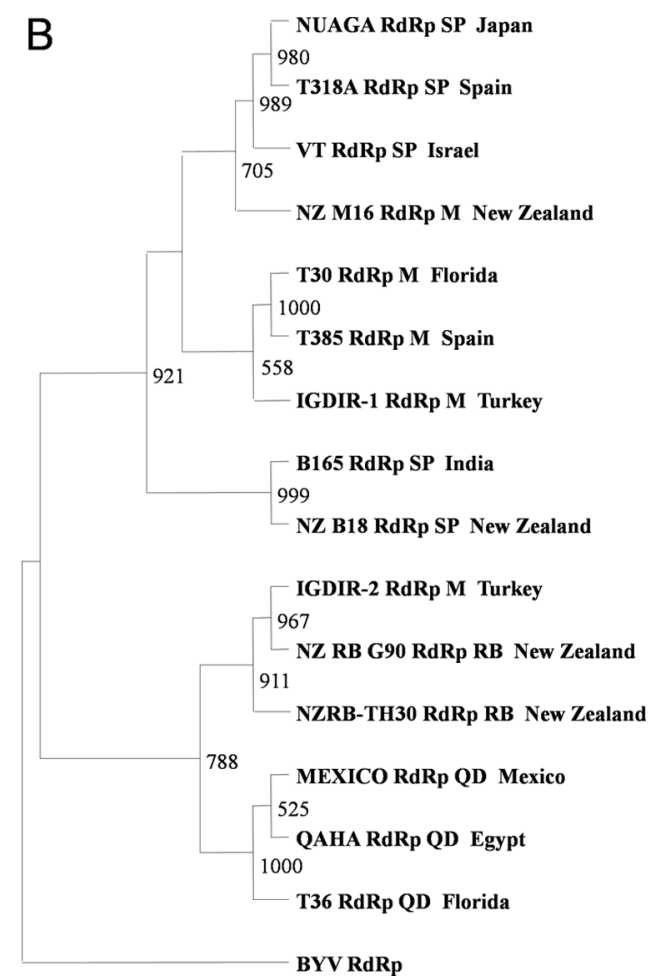

Fig. 5. Phylogenetic analyses of the amino acid sequences of the $\mathrm{CP}(\mathrm{A})$ and the RdRp (B) genes of Iğdır isolate with other CTV isolates from different citrus growing regions of the world. The origin and biological property of each isolate are shown after the isolate number. M: mild, SY: seedling yellows, QD: quick decline SP: stem pitting. Bootstrap values are indicated on the node of the three. The GenBank accession numbers for the Iğdır CP-1, CP-2, RdRp-1 and RdRp-2 are KC349866, KC349867, KC349868 and KC349869, respectively. 
genes of Iğdır isolates were clustered separately with different CTV isolates having diverse biological activity. While the RdRp-1 was clustered with T30 and T385, two wellcharacterized mild isolates from Florida and Spain, respectively, the RdRp-2 was most similar to NZRB-G90 and NZRB-TH30 two well-characterized RB and SP causing isolates from New Zealand (Fig. 4B). These result clearly demonstrated that the Iğdır isolate biologically described as a mild isolate actually contains mild and severe strains as mixture.

\section{Discussion}

Citrus tristeza virus is reportedly present in Turkey for about fifty years but it did not cause any widespread epidemics and economical losses in citrus mainly grown on CTV-sensitive sour orange rootstocks (Baloglu and Birisik, 2009; Y1lmaz, 1999). Epidemiology and destructiveness of CTV depends on the type of scion rootstock combination used for production, the presence of vector species and type(s) of strains found in a specific region. Therefore, besides knowing the alternative rootstocks and keeping efficient vectors out, the characterization of strains is very critical for prevention of CTV epidemics in Turkey. Although CTV isolates found in main citrus growing regions of Turkey were biologically and serologically characterized (Baloğlu, 1988; Korkmaz, 2002; Y1lmaz and Baloglu, 1998) the molecular characteristics of CTV isolates of Turkey is mainly unknown. Here we report molecular characterization of the first identified CTV isolates, Iğdır, using sequences of the $\mathrm{CP}$ and the RdRp coding regions of its genome.

Molecular analysis of the Iğdır isolate with the MCA13 monoclonal antibody (Permar et al., 1990) and bi-directional PCR developed based on the MCA13 epitope (Çevik et al., 1996) revealed that it contains MCA13 epitope indicating the presence of severe strains of CTV. The MCA13 epitope was previously characterized and while MCA13 reactive severe strains contain phenylalanine $(\mathrm{F})$ at position 124 of the $\mathrm{CP}$, mild isolates unrecognized by MCA13 have tyrosine (T) at the same position (Pappu et al., 1993) Sequence analysis of the CP of the Iğdır isolate showed that it contained $\mathrm{F}$ at position 124 of the CP confirming the presence of MCA13 epitope. Since presence of the MCA13 epitope predominantly indicates severe strains such as QD, SP and SY, these analyses clearly showed the presence of severe strains in the Iğdır isolate. Although we previously reported the presence of MCA13 reactive strains in Turkey (Korkmaz et al., 2008), finding of this study further confirms and clearly demonstrates the presence of the MCA13 epitope by sequencing of the $\mathrm{CP}$ gene, in addition to a positive antibody reaction, in an isolate previously described as mild.
Phylogenetic analysis of amino acid and nucleotide sequences of viral genes has been used for strain identification and molecular characterization. Phylogenetic analyses of CTV isolates were mainly conducted using the CP gene sequences. Comparison of the $\mathrm{CP}$ gene of biologically and geographically different CTV isolates revealed that the $\mathrm{CP}$ gene sequence correlated with biological activity or geographical origin of isolates (Herrera-Isidrón et al., 2009; Mawassi et al., 1993; Pappu et al., 1993b; Roy et al., 2003). Therefore, it is commonly used for identification of newly discovered strains and genetic relationship among strains of CTV from different citrus growing regions. On the other hand, genome sequences of CTV strains demonstrated that while the 3 ' half of the genome is highly conserved, significant sequence variation was observed in the 5 ' half of the genome (Albiach-Marti et al., 2000a; Mawassi et al., 1996; Suastika et al., 2001; Vives et al., 1999; Yang et al., 1999). Therefore, two genomic regions, the $\mathrm{CP}$ and $\mathrm{RdRp}$, representing respectively the $3^{\prime}$ and $5^{\prime}$ half of the genome were utilized for molecular characterization of Iğdır isolate. Comparison of sequences obtained from two randomly selected clones of the $\mathrm{CP}$ and the $\mathrm{RdRp}$ genes revealed that two cloned CP genes were identical but the RdRp genes were significantly different from each other suggesting a mixed infection with two different strains. Comparison and phylogenetic analysis of the $\mathrm{CP}$ and $\mathrm{RdRp}$ genes with respective genes of biologically and geographically different CTV isolates available in the GenBank databases revealed that the CP gene and the one of the RdRp gene were most similar to and grouped with severe SP isolates including NZRBTH30, a RB isolate from New Zealand (Harper et al., 2010) but the other RdRp gene was more closely related with mild isolates and phylogenetically grouped with mild T30 and T385. This finding suggested that the Iğdır isolate contains both mild and severe components. Similarly, isolates containing mixed infection of mild and severe strains in the same tree was previously reported in different citrus growing regions (Harper et al., 2009; Sentandreu et al., 2006). Particularly one Spanish isolate contain both mild and severe strains which were separated by aphid transmission and host passage and characterized in detail (Ayllon et al., 2006; Sentandreu et al., 2006). Similarly, some CTV isolates from New Zealand were sequenced and genomes of different strains were obtained from the same isolates (Harper et al., 2009). These and other findings clearly showed that mixed infections are common and the component of mixed infection can be separated by aphid vectors experimentally as well as naturally in the field.

Therefore, from epidemiological and control point of view it is important to know the biological, serological and molecular characteristics of CTV isolates in the region. Biological characterization of the Iğdır isolate was previ- 
ously completed and based on the reaction in indicator plants it was considered a mild isolate (Baloğlu, 1988; Y1lmaz and Baloglu, 1998; Korkmaz, 2002). The finding in this study showed that the Iğdır isolate actually contains mixed infections of mild and severe SP isolates. Since the biological indexing of the Iğdır isolate was done by graft inoculation all components of the mixed infection graft inoculated and strains in the isolate were not separated. Therefore, the mild nature of the Iğdır isolate in the indicator plant can be explained by interaction of different strains and/or cross protection of severe component by the mild strains found together. Determination of this has to await separation of mixed strains by aphid transmission.

Citrus tristeza virus is present in all in main Citrus-growing regions of the Mediterranean coast for many years (Baloğlu, 1988; Y1lmaz and Baloglu, 1998; Korkmaz, 2002) and recently reported in other Citrus-growing region of Turkey (Korkmaz et al., 2008). Studies indicated that virus is not spreading constantly from tree to tree but rather found sporadically (Baloğlu, 1988; Y1lmaz and Baloglu, 1998; Korkmaz, 2002; Korkmaz et al., 2008). This is probably due to the absence of the efficient vector T. citricida. Current predominant vector is $A$. gossypii, which unable to transmit CTV efficiently (Roistacher and Bar-Joseph, 1984; 1987). However, possible introduction of $T$. citricida may change the situation. It has been well documented in Florida that the predominant strain profile was dramatically changed after introduction of T. citricida and severe SP isolates become more prevalent (Halbert et al., 2004).

This study provides serological and molecular data as well as sequence information for the presence of severe strain component in the previously identified Turkish CTV isolate Iğdır, which is known as a mild isolate. Therefore, it is certain that the severe strains of CTV are actually present in citrus producing areas of Turkey. These strains are presumably transmitted but are not separated from mild strains by transmission by $A$. gossypii in nature in the absence of the most efficient vector, $T$. citricida. A possible introduction of $T$. citricida, which is currently found in Spain and Portugal, into Turkey may cause efficient transmission of severe components in so-called mild isolates and may change the predominant strain profile. Newly transmitted predominant severe strains could result in epidemics in citrus growing regions of Turkey where the majority of citrus is grafted on CTV-sensitive sour orange rootstocks. Therefore, the CTV isolates and/or strains found in Turkey should be detected, identified characterized in genetic diversity and epidemiological point of view and CTV resistant rootstocks and scions should be developed in preparation for the inevitable results of $T$. citricida introduction into Turkey.

\section{Acknowledgments}

This study was conducted by a grant from the Scientific and Technological Research Council of Turkey (TÜBITAK) project number $104 \mathrm{O} 584$.

\section{References}

Albiach-Marti, M. R., Mawassi, M., Gowda, S., Satyanarayana, T., Hilf, M. E., Shankar, Sç, Almira, E. C., Vives, M. C., Lopez, C., Guerri, J., Flores, R., Moreno, P., Garnsey, S. M. and Dawson, W. O. 2000. Sequences of Citrus tristeza virus separated in time and space are essentially identical. J. Virol. 74:6856-6865.

Ayllón, M. A., Rubio, L., Sentandreu, V., Moya, A., Guerri, J. and Moreno, P. 2006. Variations in two gene sequences of Citrus tristeza virus after host passage. Virus Genes 32:119-128.

Baloğlu, S. 1988. Identification, Purification, Serology (with ELISA and SDS-Immunodiffusion tests), and properties of Citrus tristeza virus (CTV) in East Mediterranean Region of Turkey. Ph.D. thesis. (in Turkish) Çukurova University, Adana, Turkey.

Baloglu, S. and Birisik, N. 2009. Historical review of Citrus tristeza virus (CTV) and its vectors in Turkey. In: Options Méditerranéennes, Series B.65 Citrus tristeza virus and Toxoptera citricidus: a serious threat to the Mediterranean citrus industry ed. by A. D’Onghia, K. Djelouah, C. N. Roistacher. pp 85-88. CIHEAM-IAMB, Bari, Italy.

Bar-Joseph, M., Garnsey, S. M. and Gonsalves, D. 1979. The Closteroviruses: a distinct group of elongated plant viruses. Adv. Virus Res. 25:93-168.

Bar-Joseph, M., Marcus, R. and Lee, R. F. 1989. The continuous challenge of Citrus tristeza virus control. Annu. Rev. Phytopathol. 27:291-316.

Bar-Joseph, M. and Lee, R. F. 1990. Citrus tristeza virus Description of Plant Viruses No, 353 Commonwealth Mycological Institute/Association of Applied Biologist Key Surrey, UK 7 pp.

Cevik, B., Pappu, S. S., Pappu, H. R., Benscher, D., Irey, M., Lee, R. F. and Niblett, C. L. 1996. Application of bi-directional PCR to Citrus tristeza virus: Detection and strain differentiation. In: Proceedings of the $13^{\text {th }}$ International Conference of $I O C V$ ed. by J. V. da Graça, P. Moreno, R. K. Yokomi, pp. 1724. IOCV, Riverside, CA.

Febres, V. J., Ashoulin, L., Mawassi, M., Frank, A., Bar-Joseph, M., Manjunath, K. L., Lee, R. F. and Niblett, C. L. 1996. The p27 protein is present at one end of Citrus tristeza virus particles. Phytopathology 86:1331-1335.

Garnsey, S. M., Gumpf, D. J., Roistacher, C. N., Civerolo, E., Lee, R. F., Yokomi, R. K. and Bar-Joseph, M. 1987. Toward a standard evaluation of the biologically properties of Citrus tristeza virus. Phytophylactica 19:151-157.

Halbert, S. E., Genc, H., Çevik, B., Brown, L. G., Rosales, I. M., Manjunath, K. L., Pomerinke, M., Davison, D. A., Lee, R. F. and Niblett, C. L. 2004. Distribution and characterization of Citrus tristeza virus in South Florida following establishment 
of Toxoptera citricida. Plant Dis. 88:935-941.

Harper, S. J., Dawson, T. E. and Pearson, M. N. 2009. Complete genome sequences of two distinct and diverse Citrus tristeza virus isolates from New Zealand. Arch. Virol. 154:1505-1510.

Harper, S. J., Dawson, T. E. and Pearson, M. N. 2010. Isolates of Citrus tristeza virus that overcome Poncirus trifoliata resistance comprise a novel strain. Arch. Virol. 155:471-480.

Ilharco, F. A., Sousa-Silva, C. R. and Álvarez, A. 2005. First report of Toxoptera citricidus (Kirkaldy) in continental Portugal and Spain (Homoptera, Aphidoidea). Agronomia Lusitana 51:19-21.

Herrera-Isidrón, L., Ochoa-Sánchez, J. C., Rivera-Bustamante, R. and Martínez-Soriano, J. P. 2009. Sequence diversity on four ORFs of Citrus tristeza virus correlates with pathogenicity. Virol. J. 6:116.

Karasev, A., Boyoko, V., Gowda, V., Nikolaeva, O. V., Hilf, M. E., Koonin, M., Niblett, C. L., Cline, K. C., Gumpf, D. J., Lee, R. F., Garnsey, S. M., Lewandoski, D. J. and Dawson, W. O. 1995. Complete sequence of the Citrus tristeza virus RNA genome. Virology 208:511-520.

Korkmaz, S. 2002. Investigation of biological properties, doublestranded RNA patterns and antigen concentration in citrus species infected with Citrus tristeza virus. Phytoparasitica 30: 420-428.

Korkmaz, S., Çevik, B., Önder, S. and Koç, N. K. 2006. First report of the presence of Citrus tristeza virus in the eastern Black Sea region of Turkey. J. Plant Path. 88(3, Sup.):69.

Korkmaz, S., Çevik, B., Önder, S. and Koç, N. K. 2008. Biological, serological, and molecular characterization of Citrus tristeza virus isolates from different citrus cultivation regions of Turkey. Turk J. Agric. For. 32:369-379.

Mawassi, M., Gafny, R. and Bar-Joseph, M. 1993. Nucleotide sequence of the coat protein gene of Citrus tristeza virus, Comparison of biologically diverse isolates collected in Israel. Virus Genes 73:265-275.

Mawassi, M., Mietkiewska, E., Gofman, R., Yang, G. and BarJoseph, M. 1996. Unusual sequence relationships between two isolates of Citrus tristeza virus. J. Gen. Virol. 177:2359-2364.

Moreno, P., Ambros, S., Albiach-Marti, M. R., Guerri, J. and Peña, L. 2008. Citrus tristeza virus: a pathogen that changed the course of the citrus industry. Mol. Plant. Pathol. 9:251268.

Morris, T. J. and Dodds, J. A. 1979. Isolation and analysis of double-stranded RNA from virus-infected plant and fungal tissue. Phytopathology 69:854-858.

Muller, G. W. and Garnsey, S. M. 1984. Susceptibility of citrus varities, species, citrus relatives, and non-rutecous plants to slash-cut machanical inoculation with Citrus tristeza virus. In: Proceedings of the $8^{\text {th }}$ International Conference of IOCV ed. by S. M. Garnsey, L. V. Timmer, A. J. Dodds, pp. 62-65 IOCV, Riverside, CA.

Niblett, C. L., Genc, H., Cevik, B., Halbert, S., Brown, L., Nolasco, G., Bonacalza, B., Manjunath, K. L., Febres, V. J., Pappu, H. R. and Lee, R. F. 2000. Progress on strain differentiation of Citrus tristeza virus and its application to the epidemiology of citrus tristeza disease. Virus Res. 71:97-106.
Nolasco, G., Santos, C., Silva, G. and Fonseca, F. 2009. Development of an asymmetric PCR-ELISA typing method for Citrus tristeza virus based on the coat protein gene. J. Virol. Methods 155:97-108.

Pappu, H. R., Manjunath, K. L., Lee, R. F. and Niblett, C. L. 1993. Molecular characterization of a structural epitope that is largely conserved among severe isolates of a plant virus. Proc. Natl. Acad Sci. USA 90:641-3644.

Pappu, H. R., Karasev, A. V., Anderson, E. J., Pappu, S. S., Hilf, M. E., Febres, V. J., Eckolff, R. M. G., McCaffery, M., Boyoko, V., Gowda, S., Dolja, V. V., Koonin, E. V., Gumpf, D. J., Cline, K. C., Garnsey, S. M., Dawson, W. O., Lee, R. F. and Niblett, C. L. 1994. Nucleotide sequence and organization of eight 3 ' open reading frames of the citrus tristeza closterovirus genome. Virology 199:35-46.

Permar, T. A., Garnsey, S. M., Gumpf, D. J. and Lee, R. L. 1990. A monoclonal antibody that discriminate strains of Citrus tristeza virus. Phytopathology 80:224-228.

Roistacher, C. N. and Bar-Joseph, M. 1984. Transmission of tristeza seedling yellow tristeza virus by Aphis gossypii from sweet orange, grapefruit, and lemon to Mexican lime, grape fruit, and lemon. In Proceedings of the $8^{\text {th }}$ International Conference of IOCV ed. by S. M. Garnsey, L. V. Timmer, A. J. Dodds, pp. 9-18. IOCV, Riverside, CA.

Rocha-Pena, M. A., Lee, R. F., Lastra, R., Niblett, C. L., OchoaCorona, F. M., Garnsey, S. M. and Yokomi, R. K. 1995. Citrus tristeza virus and its aphid vector Toxoptera citricida Threats to citrus production in the Caribbean and Central and North America. Plant Dis. 79:437-445.

Roistacher, C. N. and Bar-Joseph, M. 1987. Aphid transmission of Citrus tristeza virus: a rewiew. Phytophylactica 19:163167.

Roy, A., Ramachandran, P. and Brlansky, R. H. 2003. Grouping and comparison of Indian Citrus tristeza virus isolates based on coat protein gene sequences and restriction analysis patterns. Arch. Virol. 148:707-722.

Sentandreu, V., Castro, J. A., Ayllón, M. A., Rubio, L., Guerri, J., González-Candelas, F., Moreno, P. and Moya, A. 2006. Evolutionary analysis of genetic variation observed in Citrus tristeza virus (CTV) after host passage. Arch. Virol. 151:875-894.

Sekiya, M. E., Lawrence, S. D., McCaffery, M. and Cline, K. 1991. Molecular cloning and nucleotide sequencing of the coat protein gene of Citrus tristeza virus. J. Gen. Virol. 72:1013-1020.

Suastika, G., Natsuaki, T., Terui, H., Kano, T., Ieki, H. and Okuda, S. 2001. Nucleotide sequence of Citrus tristeza virus seedling yellow isolate. J. Gen. Plant Pathol. 67:73-77.

Vives, M. C., Rubio, L., Lopez, C., Navas-Castillo, J., AlbiachMarti, M. R. Dawson, W. O., Guerri, J., Flores, R. and Moreno, P. 1999. The complete genome sequence of the major component of a mild Citrus tristeza virus isolate. J. Gen. Virol. 80: 811-816.

Yang, Z. N., Mathews, D. M., Dodds, J. A. and Mirkov, T. E. 1999. Molecular characterization of an isolate of Citrus tristeza virus that causes severe symptoms in sweet orange. Virus Genes 19:131-142.

Y1lmaz, M. A. 1999. Virus and Virus-like diseases of citrus in 
Turkey In: Options Méditerranéennes, Proceedings of the Mediterranean network on certification of citrus 1995-1997 eds., G. P. Martelli, A. M. D'Onghia, pp. 85-93 CIHEAMIAMB, Bari, Italy.

Y1lmaz, M. A. and Baloglu, S. 1998. Detection of CTV by Immunoprinting in the Eastern Mediterranean Region of Turkey. In: Options Méditerranéennes, Series B.21 Proceedings of the Mediterranean Network on Certification of Citrus. pp. 129-
133. CIHEAM-IAMB, Bari, Italy.

Yokomi, R. K., Lastra, R., Stoetzel, M. B., Damsteegt, V. D., Lee, R. F., Garnsey, S. M., Gottwald, T. R., Rocha-Pena, M. A. and Niblett, C. L. 1994. Establishment of the brown citrus aphid (Homoptera:Aphididae) in Central America and the Caribbean Basin and transmission of Citrus tristeza virus. J. Econ. Entomol. 87:1078-1085. 